\title{
Severity assessment of acute pancreatitis: applying Marshall scoring system
}

\section{Avaliação da gravidade da pancreatite aguda: aplicando o sistema de pontuação de Marshall}

André Lanza Carioca'; Debora Rodrigues Jozala'; ' lucas Oliveira de Bem¹; Jose Mauro da Silva Rodrigues, TCBC-SP¹

\author{
A B S T R A C T
}

\begin{abstract}
Objective: To analyze the effectiveness of the Marshall scoring system to evaluate the severity of acute pancreatitis (AP). Methods: We performed a prospective, observational study in 39 patients with AP evaluated by the Marshall scoring system and the Ranson criteria (admission and 48 hours). We assessed the progression of the disease for seven days and compared the data of the two criteria. Results: Seven patients died during the observation period and one died afterwards. All deaths had shown failure of at least one system by the Marshall method. Conclusion: The Marshall scoring system may be used as an effective and simplified application method to assess the severity of acute pancreatitis.
\end{abstract}

Key words: Pancreatitis. Multiple Organ Failure. Organ Dysfunction Scores. Pancreatitis, Acute Necrotizing.

\section{INTRODUCTION}

A cute pancreatitis (AP) is defined as an acute inflammatory process of the pancreas, which can also involve peripancreatic areas or more distant organs, being most commonly caused by gallstones and chronic alcohol consumption'. Its clinical presentation involves abdominal pain in the epigastric and periumbilical region, with referral, for example, to the lumbar region. Nausea, vomiting and fever often accompany the clinical setting and hypotension may be present due to liquid sequestration ${ }^{2}$.

The clinical course of AP is variable, since there are cases of complete resolution and those of occurrence of multiple organ failure, which can be lethal. The determination of AP's severity is essential in view of the prognosis and proper treatment selection ${ }^{3}$. Accordingly, various classifications have been proposed to determine the severity of each clinical situation, the one of Atlanta ${ }^{4}$ being the most used.

Currently, it is assumed that the number of affected organs, the start time and duration of organ dysfunction influence AP's evolution, which diverges from the Atlanta classification, which includes only the presence or absence of such condition ${ }^{5-7}$.

Regarding severe $\mathrm{AP}$, the Atlanta classification establishes the Ranson ${ }^{8}$ or APACHE $\|^{9}$ criteria for characterization of severity. These methods, however, have limitations reported by other studies ${ }^{10-15}$. In 2008, the review of the Atlanta classifivcation ${ }^{16}$ defined the severity of acute pancreatitis, at least in the first week, is based on clinical components and suggested that the persistence of a systemic inflammatory response syndrome and / or organ failure should be considered.

The dysfunction or organ failure is recognized as the most important determinant of prognosis in the early stage ${ }^{17}$ and is possibly related to bacterial and endotoxin translocation that favor the evolution of the clinical picture for sepsis and for multiple organ failure syndrome. Moreover, there are claims that, in severe AP, there is activation of reflex anti-inflammatory response and reduced immune capacity, which predisposes to organ failure and secondary infections ${ }^{2,18}$.

For the definition of organ failure, the revision of the Atlanta classification suggested the Marshall scoring system $^{19}$, establishing a score $\geq 2$ to determine the failure of an organ. It uses $\mathrm{pO}_{2} / \mathrm{FiO}_{2}$ as parameters for the respiratory system, serum creatinine in $\mathrm{mmol} / \mathrm{L}$ or $\mathrm{mg} / \mathrm{dL}$ for renal evaluation and systolic blood pressure in $\mathrm{mmHg}$ for the cardiovascular system. This system has been chosen by some authors $11,16,20$ due to its convenience.

This paper aims to examine the effectiveness of the Marshall scoring system in evaluating AP severity.

\section{METHODS}

We conducted a prospective, observational study, with 39 consecutive patients with AP diagnosis admitted to

1. Departamento de Cirurgia Faculdade de Ciências Médicas e da Saúde (FCMS) - PUCSP, SP, Brasil. 
the Conjunto Hospitalar de Sorocaba. Sociodemographic, clinical, laboratory and radiological data were collected daily by consulting their medical records for up to seven days for all cases. The Ranson and Marshall scoring systems were applied in all patients and compared using the McNemar chi-square test. The research project number 14260 was approved by the Ethics in Human Research Committee of the Faculdade de Ciências Médicas e da Saúde at PUC-SP.

\section{RESULTS}

The patients' ages ranged from 20 to 88 years, 17 were men, and 22, women. The Ranson score mode at admission was zero, and at 48 hours, one (Figure 1). The Marshall system mode was zero (Figure 2).

Of the 39 patients observed, 11 were classified with severe acute pancreatitis by the Marshall system (score $\geq 2$ ) and eight patients by the Ranson score (score $\geq 3$ ), with agreement between the two scoring systems in seven cases. When applying the McNemar chi-square test, we found $\chi^{2}=1.8$ with $p=0.1797$, there hence being agreement between the results presented by both systems ( $p>0.05)$.

Seven patients died in one week and one died after this. Of those who died in seven days, all had some type of organ failure by the Marshall scoring system. Nine patients developed respiratory failure, seven cardiovascular failure and six, kidney failure (Table 1).

Among the patients who died in seven days, three had Ranson score $\geq 3$ at admission and four showed score $\geq 3$ in 48 hours. Among those who died, four had high Marshall and Ranson scores, with disagreement only in three cases, in which there were low Ranson scores, but high Marshall ones.

\section{DISCUSSION}

Several classifications are presented in the literature in an attempt to determine AP severity. The Atlant classification ${ }^{4}$ was introduced in 1992 and defined the categories of mild and severe AP. The latter was defined as pancreatitis associated with organ failure or local complications. Organ failure, according to this system, is defined by shock, respiratory failure, renal failure and gastrointestinal bleeding (more than $500 \mathrm{ml} / 24$ hours). Necrosis, abscess, pseudocyst are among the possible local complications.

The definition for severe AP proposed by the review of the Atlanta classification ${ }^{16}$ includes persistent systemic inflammatory response and / or development of organ failure. We observed seven patients with organ failure among the dead in a week of hospitalization. However, despite its use established in the Atlanta classification ${ }^{4}$, it is

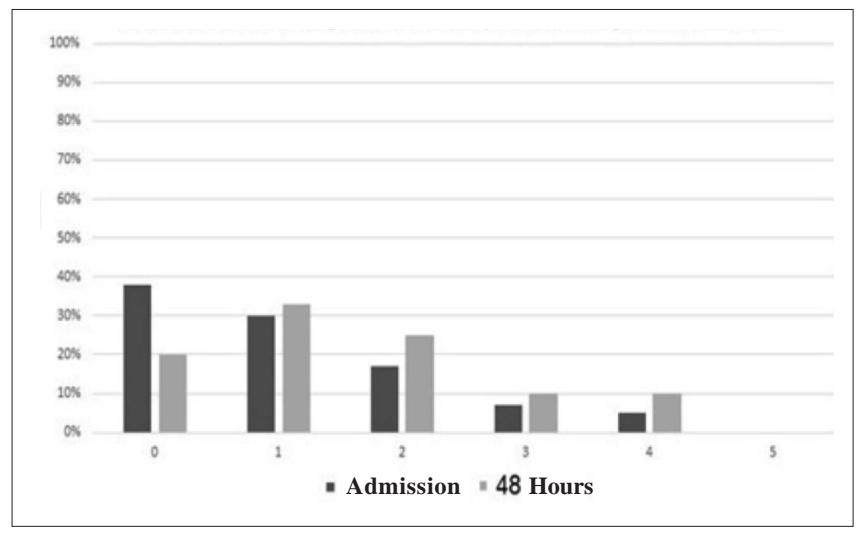

Figure 1 - Distribution of cases according to the Ranson score.

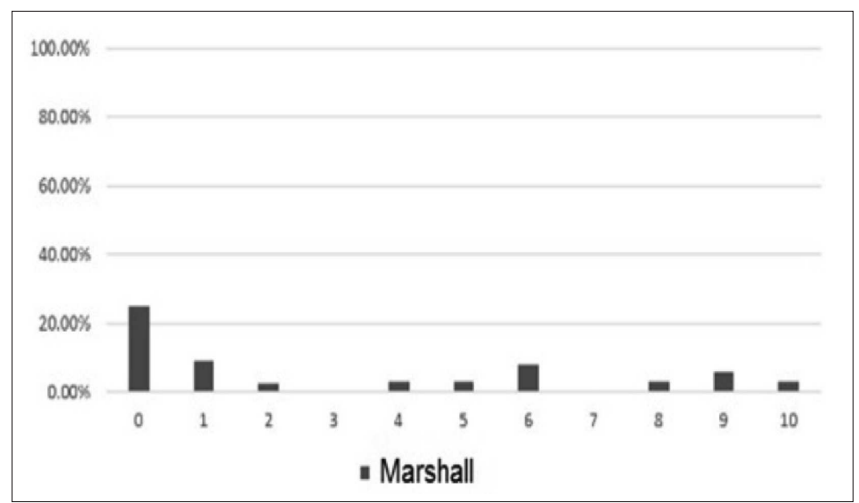

Figure 2 - Distribution of cases according to the Marshall score.

Table 1 - Failure of specific organs according to the Marshall scoring system.

\begin{tabular}{lcc}
\hline System & \multicolumn{2}{c}{ Frequency } \\
& \% & $\mathbf{n}$ \\
\hline Respiratory & 23 & 9 \\
Cardiovascular & 18 & 7 \\
Renal & 15 & 6 \\
None & 72 & 28 \\
\hline
\end{tabular}

Source: medical records of Conjunto Hospitalar de Sorocaba.

a method that requires 48 hours to complete the evaluation, hampering the analysis within the first 24 hours, which is important in view of the prevention of possible adverse events ${ }^{10-12}$.

Besides the Ranson scoring system, the Atlanta classification also proposes the APACHE II score $^{9}$, which can be used before 24 hours and correlates better with prognosis. However, it is complex, it requires more time for execution, and does not properly diagnose necrotizing pancreatitis at admission ${ }^{13-15}$.

Already pointed out and used in other studies as a way to assess AP severity, the Marshall scoring system emerged in the literature as a better applicability proposal 
due to its ease of use $16,20,21$. Moreover, its specificity is greater than $90 \%$ for predicting AP severity at 24 and 48 hours ${ }^{21}$.

We also found correlation of high Ranson scores with high Marshall scores. Thus, considering that the determination of gravity is essential to the proposed treatment and that this, in turn, is critical for prognosis, it is necessary to use methods that render the best classification in AP cases. When considering organ dysfunction or failure as the central prognostic factor, methods that cover these characteristics have been used with excellent results. In our study, the strong correlation of scores with clinical outcome confirms the effectiveness of the aforementioned method with regard to the classification of AP severity.

Considering that the Marshall scoring system corresponded with the clinical course of AP patients and the need for a method to evaluate organ failure in determining AP severity, we conclude that the Marshall scoring system can be used as an effective and simplified application method to assess the severity of acute pancreatitis.

\section{R E S U M O}

Objetivo: analisar a eficácia do sistema de pontuação de Marshall na avaliação da gravidade da pancreatite aguda. Métodos: fo realizado um estudo prospectivo e observacional em 39 pacientes com PA, avaliados pelo sistema de pontuação dos critérios de Marshall e Ranson (admissão e 48 horas). Foi avaliada a evolução do quadro clínico durante sete dias e comparados os dados dos dois critérios. Resultados: sete pacientes morreram durante o período de observação e um morreu após esse período. Todos os óbitos possuíam, pelo sistema de Marshall, falência de pelo menos um sistema. Conclusão: concluímos que o sistema de pontuação de Marshall pode ser utilizado, por ser um método eficaz e de aplicação simplificada, para avaliar a gravidade da pancreatite aguda.

Descritores: Pancreatite. Insuficiência de Múltiplos Órgãos. Escores de Disfunção Orgânica. Pancreatite Necrosante Aguda.

\section{REFERENCES}

1. Carroll JK, Herrick B, Gipson T, Lee SP. Acute pancreatitis: diagnosis, prognosis, and treatment. Am Fam Physician. 2007;75(10):151320.

2. Beger HG, Rau BM. Severe acute pancreatitis: Clinical course and management. World J Gastroenterol. 2007;13(38):5043-51.

3. Mayumi T, Takada T, Kawarada Y, Hirata K, Yoshida M, Sekimoto $M$, et al. Management strategy for acute pancreatitis in the JPN Guidelines. J Hepatobiliary Pancreat Surg. 2006;13(1):61-7.

4. Bradley EL 3rd. A clinically based classification system for acute pancreatitis. Summary of the International Symposium on Acute Pancreatitis, Atlanta, Ga, September 11 through 13, 1992. Arch Surg. 1993;128(5):586-90.

5. Petrov MS, Windsor JA. Classification of the severity of acute pancreatitis: how many categories make sense? Am Gastroenterol. 2010;105(1):74-6.

6. Lankisch PG. Natural course of acute pancreatitis: what we know today and what we ought to know for tomorrow. Pancreas. 2009;38(5):494-8.

7. Buter A, Imrie CW, Carter CR, Evans S, McKay CJ. Dynamic nature of early organ dysfunction determines outcome in acute pancreatitis. Br J Surg. 2002;89(3):298-302.

8. Ranson JH, Rifkind KM, Roses DF, Fink SD, Eng K, Spencer FC. Prognostic signs and the role of operative management in acute pancreatitis. Surg Gynecol Obstet. 1974;139(1):69-81.

9. Knaus WA, Draper EA, Wagner DP, Zimmerman JE. APACHE II: a severity of disease classification system. Crit Care Med. 1985;13(10):818-29.

10. Hirota M, Takada T, Kawarada Y, Hirata K, Mayumi T, Yoshida $M$, et al. JPN Guidelines for the management of acute pancreatitis: severity assessment of acute pancreatitis. J Hepatobiliary Pancreat Surg. 2006;13(1):33-41

11. Singh VK, Wu BU, Bollen TL, Repas K, Maurer R, Johannes RS, et al. A prospective evaluation of the bedside index for severity in acute pancreatitis score in assessing mortality and intermediate markers of severity in acute pancreatitis. Am J Gastroenterol. 2009:104(4):966-71
12. Banks PA, Freeman ML; Practice Parameters Committee of the American College of Gastroenterology. Practice guidelines in acute pancreatitis. Am J Gastroenterol. 2006;101(10):2379-400.

13. Rosa I, Pais MJ, Fátima C, Queiroz A. Pancreatite aguda: actualização e proposta de protocolo de aborgadem. Acta Med Port. 2004;17(4):317-24.

14. Lankisch PG, Warnecke B, Bruns D, Werner HM, Grossmann F, Struckmann $K$, et al. The APACHE II score is unreliable to diagnose necrotizing pancreatitis on admission to hospital. Pancreas. 2002;24(3):217-22

15. Stevens T, Parsi MA, Walsh RM. Acute pancreatitis: problems in adherence to guidelines. Cleve Clin J Med. 2009;76(12):697-704.

16. Acute Pancreatitis Working Group. Revision of the Atlanta classification of acute pancreatitis (3rd (revision). 2008.

17. Dimagno MJ, Wamsteker EJ, Debenedet AT. Advances in managing acute pancreatitis. F1000 Med Rep. 2009:1:59.

18. Mentula $P$, Kylänpää $M L$, Kemppainen $E$, Jansson SE, Sarna $S$, Puolakkainen $\mathrm{P}$, et al. Plasma anti-inflammatory cytokines and monocyte human leucocyte antigen-DR expression in patients with acute pancreatitis. Scand J Gastroenterol. 2004;39(2):178-87.

19. Marshall JC, Cook DJ, Christou NV, Bernard GR, Sprung CL, Sibbald WJ. Multiple organ dysfunction score: a reliable descriptor of a complex clinical outcome. Crit Care Med. 1995:23(10):1638-52.

20. Johnson CD, Abu-Hilal M. Persistent organ failure during the first week as a marker of fatal outcome in acute pancreatitis. Gut. 2004;53(9):1340-4

21. Campos T, Parreira JG, Assef JC, Rizoli S, Nascimento B, Fraga GP. Classificação de gravidade na pancreatite aguda. Rev Col Bras Cir 2013;40(2):164-8.

Received at: 05/11/2014

Accepted for publication: 21/01/2015

Conflict of interest: none.

Source of funding: none.

\section{Mailing address:}

Lucas Oliveira de Bem

E-mail: loliveira_|x@hotmail.com 